\title{
Tubjaku Kosterkini loitsud
}

\author{
$\underline{\text { Aado Lintrop }}$
}

Tubjaku Kosterkinit (1921-1989) võib pidada viimaseks suureks nganassaani shamaaniks. Tema isa Djuhade Kosterkin sai laialdaselt tuntuks tänu Andrei Popovile, kes oma 1936. aastal ilmunud raamatu "Tavgitsõ" ühe peatüki pühendas nganassaani shamanismile. Selles kasutatud materjal pärines valdavalt Djuhadelt. Tema kutsumusnägemusi ja puhta koja rituaali kirjeldust on kas osaliselt või tervikuna tsiteerinud paljud teadlased, teiste hulgas ka M. Eliade (vt. Eliade 1974: 38-42).

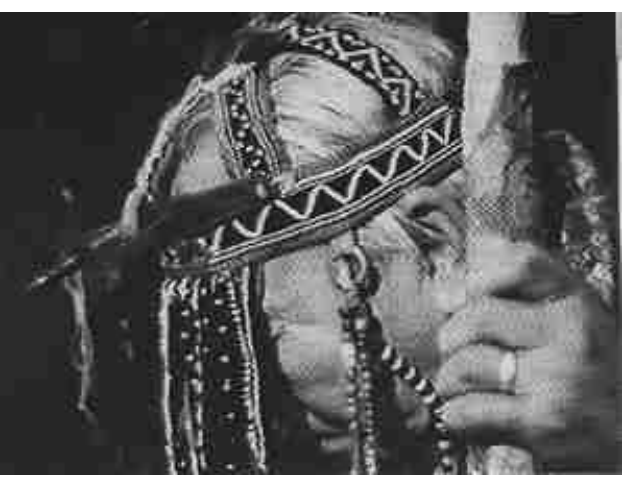

Räägiti, et enne Tubjaku sündi surnud kõik Djuhade poeglapsed imikueas. Kui Djuhade esimene naine (tal oli kolm naist) taas käima peal oli, ennustanud Djuhade, et nüüd sünnib poeg, kes teistele poegadele elutee avab. Tubjaku sündinud "särgis". Nimi anti talle kaelal oleva nööbikujulise sünnimärgi järgi. Djuhade ennustus osutus õigeks, sest pärast Tubjakut sünnitasid naised talle veel poegi.

Aastaid elas Tubjaku tundras küti, kalamehe, põdrakasvataja ja praktiseeriva shamaanina. 40-te aastate lõpus, kui kohalikud võimud alustasid aktiivset shamanismi likvideerimise poliitikat, arreteeriti ta ja mõisteti laagrisse "ametiseisundi kuritarvitamise" ettekäändel, s.o. mitte sellepärast, et ta oli shamaan, vaid sellepärast, et ta võttis oma töö eest tasu. Pärast vangist vabanemist jätkas Tubjaku loitsimist. Ametivõimud teda rohkem ei tülitanud.

Tubjaku isa Djuhade polnud esimene shamaan perekonnas. Tubjaku noorema venna Borissi jutustatud muistendi kohaselt põlvnesid kõik Kosterkinite soost shamaanid vanast sugukonnashamaanist, kes ainukesena koos oma lastega elas üle suure epideemia. Tema vanimal pojal oli Neiminginimeline tütar, kes sai lapse Kotkas-jumalaga. Poisile pandi nimeks Lambie ning ta sai suureks shamaaniks. Mõned arvavad, et Kosterkinite shamaanianne pärineb just Neimingilt (Gratsheva 1981: 73-74; 1983: 134), ent Borissi jutust järeldub, et Djuhade vaarisaks oli hoopis Neimingi onupoeg (või onupoja poeg) Sõrõ'a (= Valge - vt. Simtshenko 1968: 206-210).

Teise muistendi kohaselt oli Djuhade esivanemate hulgas sabaga shamaan. "Hunt hakkas karja juures käima ja põtru murdma. Keegi ei saanud teda kätte. Viimaks ütles shamaan: "Ma püüan ta siiski kinni. On ju hundil nagu igal teiselgi loomal oma ema." Ta loitsis kolm päeva järjest, siis ütles: "Panin hundi oma naise sisse, küll te näete, milline laps sünnib." Sündis sabaga laps - Djuhade vanaisa. Ta sai vägevaks shamaaniks ja käis kogu elu sabaga ringi."(Popov 1984: 109.) Galina Gratshevale räägiti teistsugune lugu. Naine, kes lapsi ei saanud, pöördus oma murega shamaani poole. Too käskis naisel kuupaistesel talveööl kojast eemale minna ja näoga kuu poole pöörduda. Naine tegi õpetuse kohaselt. Kui ta seal seisis, jooksis hunt ta jalgade vahelt läbi. Pärast sünnitas naine sabaga poja, kelle nimeks sai Taibula (Saba). Viimasest sai vägev shamaan. (Gratsheva 1979: 202.)

Djuhade tütar Nobopte oli samuti shamaan. Tema peamiseks abivaimuks oli barusi - müütiline ükskäsi-üksjalg-ükssilm olevus. Kuna barusit peeti inimestele ohtlikuks, ei julgenud paljud abi saamiseks Nobopte poole pöörduda. Pärast seda, kui Nobopte oli mehele läinud, asustas isa barusi ühe oma abivaimu sisse (Gratsheva 1981: 74,76). Ka Tubjaku noorem vend Demnime (1926-1980) oli shamaan. 
Tubjaku nägi 7-8 aastasena unes, et läks tütarlapsest teejuhi saatel naise juurde, kelle nägu ta ei vaadanud ja sisenes temasse suguelundite kaudu. See naine kinkis talle abivaimuks kõhna emapõdra. Hiljem täie varustusega loitsides alustas ta laulmist just selle emapõdra meloodiaga (Gratsheva 1983: 136). Tubjaku tähtsaimaks abivaimuks oli aga Hotarie-nimeline põhjapõder, keda ta kirjeldas kaheksajalgse põdrapullina. Shamaani kutsel ilmudes lisas Hotarie oma nimele mitmesuguseid situatsiooniga sobivaid täiendeid, nagu Veetäkk, Veekotkas, Maa Nael jne (Kosterkina, Helimski 1994: 22). Oma abivaimude väge täiendas Tubjaku puhta koja rituaalidel, mille käigus ta külastas erinevaid üleloomulikke olendeid ja sai neilt kingitusi enesele ja oma kodakondseile. Nii sai ta Kümmejumalalt raudse kodustatud põhjapõdra, Jäiselt jumalalt sarvedeta põhjapõdra, veteemalt veetüdruku, päikeseemalt seitse päikesetüdrukut, Rõugetelt seitse koertega naist ning Läänejumalalt raudhobuse (Gratsheva 1983: 142, 144). Raudhobuse nimi oli Mikulushka (võib-olla kaudselt seotud püha Nikolai ehk Nikolai Imetegijaga) ja tema spetsialiteediks oli ametiasjade lahendamine. Lisaks neile oli Tubjakul palju muidki vaime: kärp, hiir, seitsme kutsikaga emahunt, seitsme sabaga koer, pruunkaru, jääkaru, mitmesugused linnud ning viimaks ka kolm inimesekujulist vaimu - kolm vanameest, kellest üks oli silmitu, teine kõrvutu ja kolmas ilma suuta (Gratsheva 1983: 144). Need vanamehed, keda Tubjaku nimetas kolmeks Hositala jumalaks, olid Hotarie peamised informaatorid, kuna silmitul oli äärmiselt terav nägemine, kõrvutu kuulis kõike (oli Tubjaku sõnul nagu raadio), suutu aga rääkis kõik edasi (Kosterkina, Helimski 1994: 22). Viimastel eluaastatel peale naise surma, kui Tubjakul polnud enam shamaanikostüümi ega trummi, ei kasutanud ta kõigi oma vaimude teenuseid. Aga kahte neist, Hotaried ja Mikulushka Raudhobust, hoidis ta alati enda käsutuses. Ta väitis, et võtab nad endaga kaasa isegi Novosibirskisse ja Moskvasse. Vaimudega reisimine ei valmistanud talle mingeid raskusi, kuna nad mahtunud lahedasti shamaaniga ühe katuse alla. Just neid kahte abivaimu kasutas ta oma kodustel väikestel shamaanirituaalidel, mida ta korraldas nii suuremate riigipühade ajal kui ka mõne erakorralise perekonda puudutava sündmuse puhul.

1989. aasta augustis külastasid Tubjaku Kosterkinit tema kodus Ust-Avami külas Jevgeni Helimski Moskvast, Juri Sheikin ja Olga Dobzhanskaja Novosibirskist, Hendrik Relve Tallinnast ning Triinu Ojamaa ja siinkõneleja Tartust. Üheskoos õnnestus jäädvustada magnetofoni- ja videolindile kaks Tubjaku kodust shamaanirituaali. Koos Tubjaku tütre Nadezhda Kosterkinaga litereeris J. Helimski rituaalide tekstid ning publitseeris need koos venekeelse tõlkega teoses "Taimõrski etnolingvistitsheskii sbornik" (Moskva 1994). Käesoleva ettekande aluseks ongi nende tekstide baasil tehtud eestikeelsed sõnasõnalised tõlked.

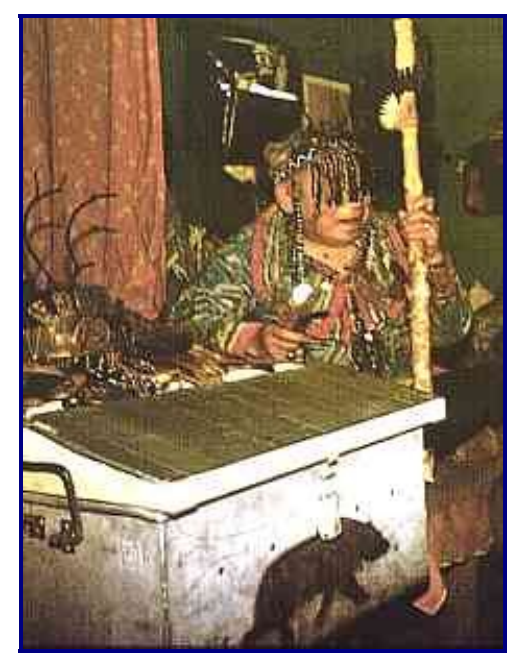

Rituaalide taustast. Kuigi esimene rituaal korraldati külaliste palvel, andis sellele siiski peamise värvingu paar päeva enne seda toimunud vahejuhtum - nimelt paugutas Tubjaku väimees purjuspäi küla peal püssi. Kuigi keegi õnnekombel viga ei saanud, ähvardas Anatolit kriminaalasi. Teiseks rituaaliks andis aga põhjuse Tubjaku poja ja pojanaise eelseisev hooajatöö külast eemal asuvas jahimeeste brigaadis.

Abivaimudest. Shamaani kutsel ilmus mõlema rituaali käigus esimesena Mikulushka Raudhobune. Kuna esimese rituaali jooksul pidi shamaan korraldama riigivõimu kompetentsi kuuluvaid asju, sai Raudhobune selle rituaali algul pikemalt sõna. Muuseas ütles ta nii (värsid 22-31):

See sinu poeg istugu siin, andku iidolitele vanne: 
"Veel kord,sellist asja ma enam ei kavatse," öelgu.

"Hotarie, endale [pandiks]

võta тu pea!

Trellidega pimedasse majja ära lase libiseda.

[Kui ma] veel kord mõne halva asja teen, siis oma pea kindlasti kaotan."

Nü̈d hästi rääkigem.

Viis loitsimiseks kõlblikku_(1)-kõik nad on minul,

Selline olles on mu nimi Häbitu.

Viimaseid värsse võib tõlgendada ka nii, et shamaan ise, olles varustatud oma viie peamise abivaimuga, on see, kellele tuleb kõigest rääkida, kelle ees ei ole tarvis häbeneda. Teise rituaali algul anti Raudhobusele vähem sõna. Siiski jõudis shamaan rituaali käigus veendumusele, et töö jahimeeste brigaadis on piisavalt "ametlik" ka Raudhobuse sekkumiseks. Enne sõnajärje Raudhobusele andmist iseloomustas teine abivaim Hotarie teda järgmiselt (värsid 814-829):

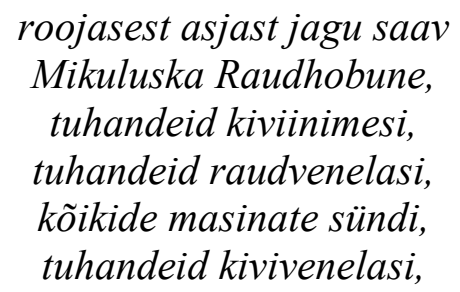

kõikide masinate tulevast sündimist määrav.

[Ta on] tuhandeid raudvenelasi, tugevate masinate minemist jagav, praegusel ajal seadust kehtestav.

Need jumalad töötavad.

Nende jumalate töötamisega kehtima pannud tugeva seaduse, kogu maa elanike tõusmise,

kivi[na] seisma on pannud,

raua[na] seisma on pannud,

oma sündimisega vanem jumal.

Tasakesi puhkama heita kavatsen.

Neist värssidest võib järeldada, et Mikulushka Raudhobune oli Tubjaku jaoks omamoodi nõukogude võimu valdajaks või haldjaks ja et shamaan püüdis seda võimu mõjutada samal kombel, kui kõiki teisi üleloomulikke olendeid. Esimese rituaali algul (värsis 38) ütleb Raudhobune shamaani suu läbi otsesõnul: Kui olen selline, nimetatakse mind Kogu Nõukogude Võim. Muidugi on võimalik neid sõnu tõlgendada ka nii, et oma viie peamise abivaimuga varustatuna on shamaanil enesel kogu võimutäius, seega suudab ta lahendada ka riigivõimu kompetentsi kuuluvaid küsimusi. Värsis 864 tutvustab Raudhobune ennast ka Taadi nime all.

Teiseks rituaalidel aktiivselt tegutsevaks abivaimuks on Hotarie, kes tutvustab ennast mõlema rituaali ajal Veekulli, Üksikettevõtja, Maa Naela, Veetäku ja Veepullina. Teda lauludes otseselt ei kirjeldata. Vaid esimese rituaali värsid 53-57

Minu nimi on Veekull.

Suvise [laagri]paiga vett joogiks ammutavad

linnas elavad seitsme maa elanikud,

[on] külma veega üles kasvanud -

seda teevad mu isa ja ema; 
ja teise rituaali värsid 683-685:

\author{
minu jaoks kaetud päeva \\ Hotarie Veepull, veeteed valdav, \\ kuidagi juba avab
}

viitavad Hotarie erilisele seotusele veega. Andrei Popovi järgi oli Tubjaku isa Djuhade peamiseks abivaimuks Huottarie - kaur (Popov 1936: 85). Ent Galina Gratsheva on väitnud, et Hottare olnud Djuhade shamaanist vaarisa nimi, mis tähendavat 'sukelduv' (Gratsheva 1983: 134). Pole võimatu, et 'sukelduv' on üks kauri eufemistlikke nimesid. Igatahes on ilmne selle abivaimu seotus Tubjaku esivanematega.

Vastavalt värssidele 478,479:

\title{
Kolm Hositala jumalat, siia ligemale tulge!
}

ja 359-361:

\section{Kõik halvad põhjused oma isale jutusta. \\ Tema kõrv kuulis, Koubtumu-jumal [on] nagu raadio.}

võib oletada, et ülejäänud abivaimud Tubjaku mainitud viiest loitsimiseks kõlbulikust on kolm Hositala-vanameest. Helimski järgi tuleneb abivaimu Koubtumu nimi verbivormist koubtu - kõrva sosistama. Kuigi tal endal pole kõrvu, kuuleb ta kõike. Teised kaks on Seimibtimi (sõnast seimi silm), kellel pole silmi, kuid kes kõike näeb ja Ngangabtumu (ngang - suu), kellel pole suud, kuid kes kõike kuuleb (vt. Kosterkina, Helimski 1994: 22).

Rituaalide ülesehitus on lihtne. Ettevalmistuste käigus toodi tuppa plekiga ülelöödud ja pruunkaru ning jääkaru piltidega kaunistatud kirst, milles Tubjaku hoidis oma väheseid allesjäänud shamaaniatribuute ja iidoleid. Vajalikud iidolid asetati lauale ning kostitati neid - piserdati piirituse või viinaga. Shamaan pani pähe narmastega peakatte ja selga dolgaani päritoluga shamaanikitli. Enne teist rituaali pöördus ta rõivastumise ajal iidolite poole pikema kõnega. Seejärel hakkasid juuresviibijad vaime kutsuma hüüetega houk, houk, tuobtusid (shamaani abilised-järgilauljad) aga alustasid abivaimu (Mikulushka Raudhobuse) kutsumise viisi, mida nad laulsid sõnadeta. Tubjaku istus, silmad kaetud, ja kõigutas käes kellukesega saua. Esimese rituaali algul kurtis ta, et "lärmi on vähe", mispeale juuresviibijad suurendasid vaimu kutsumisele suunatud jõupingutusi. Et Tubjaku siiski päris rahule ei jäänud, sellest tunnistavad teise rituaali kestel pojale etteheitena suunatud sõnad (värsid 353-357):

\section{Siia sõita kavatsetavatest lastest sa ju kuulsid, kuhu sa kadusid? (2) Oma põhjusest räägi! Ainult su vanema venna ja vanema õe_(3) [poolt tehtud] lärmi kõlamisest jumalale ei piisa. (4)}

Kaasalauljate rolli kohta on Tubjaku Galina Gratshevale öelnud, et suurte rituaalide ajal kordas kogu kojas istuv rahvas shamaani sõnu, sest "mida rohkem rahvast, seda kergem on (shamaanil) minna." Inimesed nagu kannaksid oma häältega shamaani ja ta abivaimud üleloomulikku maailma. (Gratsheva 1983: 140.) Levinud oli ka ettekujutus sellest, et ühes shamaani hinge ning abivaimudega sooritasid rännaku ka kõigi rituaalis osalejate hinged (samas; ka Popov 1936: 76).

Loitsudest. Kui shamaan tundis, et vaim on ilmunud, alustas ta laulu kutsutud vaimu viisil. Laul koosnes erineva pikkusega fragmentidest (alates paarist värsist kuni mitmesaja värsireani), iga frag- 
ment algas sõnadega tamaani, tamaani, mis tähistasid seda, et shamaan, kes fragmentide vahel suhtles juuresviibijatega iseenda isikus, kommenteerides ja täpsustades lauluga öeldut, esitas edaspidi jälle vaimule kuuluvat teksti. Abilised kordasid iga shamaani lauldud värssi. Vaimuga suhtlemine toimus vaid vaimu initsiatiivil, see tähendab, et kõigepealt pöördus vaim shamaani suu läbi kellegi juuresviibija poole ning esitas vastamist nõudva küsimuse või oletuse. Seepeale lõpetas shamaan laulmise ja kommenteeris vajaduse korral küsimust. Kui see polnud ikka arusaadav, üritas üks tuobtusidest seda omakorda selgitada. Kui miski ei aidanud või saadud vastus shamaani ei rahuldanud, alustas ta uut laulufraasi, millega küsimust teisiti formuleerida püüdis. Mõnikord käisid selle juurde üsnagi halvustavad sõnad adressaadi vähese taiplikkuse kohta. Näiteks värsid 390-394, suunatud miniale:

\title{
Tamaani, tamaani!
}

Talle lihtsameelsele inimesele pole selge:

sellesse oma majja kui tulid,

segadusseajava sõna

kelleltki kuulsid.

Esimese rituaali sissejuhatavas fragmendis tervitab Raudhobune vanu tuttavaid ja tuletab meelde üheskoos tehtud tööd (värsid 1-16):

\author{
Tamaani, tamaani! \\ Mu nimi on Raudne Hobune, \\ [olen] nõukogude võimu ajal ilmunud. \\ Näen teid kõiki - \\ kuni valmistute [rituaaliks] \\ silmitsen teid hoolega. \\ Moskva[s olemise] ajal_(5) \\ olin mina see, kes töötas. \\ Jura, mu poeg, sellele maale \\ oled ju toonud oma silmad. \\ Zhenja, mu poeg, sellele maale \\ oled ju toonud oma näo. \\ Teisi teie seast ma ei tunne, \\ Moskva ajal ma neid ei näinud. \\ Hästi üksteist tervitame! \\ Seda mu maad väidetavasti Hotarieks nimetatakse.
}

Järgneb pööre pakiliste perekonnaprobleemide lahendamise poole. Seda võib tõlgendada ka nii, et Mikulushka Raudhobune palub külalistelt luba omade asjadega tegelemiseks (värsid 33-36):

millist asja pean tegema?

Praegu on kõik mu töö segi.

Oletame, [et] ütlete: "Sina oma tööd tee."

Kui on nii, siis saavad kõik mu asjad korda.

Järgnenud vestluse käigus palus shamaani tütar Mikulushkat korraldada asjad nii, et juhtunu ei tooks kaasa halbu tagajärgi.

Teist rituaali sissejuhatav fragment piirdub vaid konstanteeringuga, et need, kes kultuseesemed tuppa tõid, talitasid õigesti. Kuna edasi tuleb tegemist vaid perekonnaasjadega, astub Mikulushka Raudhobune kõrvale sõnadega (värsid 341-348): 


\author{
Viie loitsimiseks kõlbliku [seast] usaldatavaim - kas pole [see] Veepull Hotarie? \\ Nü̈̈d kavatseb ta rääkida. \\ Nende laste sarnaselt mina kirjutajaks hakkan. \\ Kui kirjutamisega hakkama saan, \\ suvise teega, talvise teega teiegi hästi hakkama saate. \\ Veepull, mu peremees, \\ suvine olev mu õhtune (ja) hommikune toit. (6) \\ Tamaani, tamaani! Hotarie kuuldavasti räägib.
}

Shamaan võrdleb ennast vaimude vahendana oma külalistega, kes neidsamu sõnu üles kirjutavad. Selliseid shamaani rolli vähendada püüdvaid märkusi esineb teisigi: minu lobisev loitsimine (154) kõiki tegemisi ja muresid ära tundmata ma ju ei lobise (373) nagu ти loitsimine õigesti lobiseb $(619,620)$.

Pikemad laulufragmendid (esimeses rituaalis 119, teises 231 värssi) on selgelt monoloogilised, mõlemad sisaldavad shamaani (või abivaimu) sisemisele arupidamisele viitavaid värsse algul môtlesin öelda, pärast seda mõtlesin öelda, edasi mõtlesin öelda, seejärel mõtlesin öelda, sel päeval mõtlesin öelda, lühidalt öeldes mõtlesin öelda (esimeses tekstis kolmel, teises viiel korral). Lühikesed laulufragmendid on selgelt dialoogilised, koosnedes pöördumisest kellegi juuresviibija poole, mõne adressaati puudutava seiga äraarvamisest ning ennustusest, mis juhtub siis, kui arvatu osutub õigeks. Näiteks teise rituaali värsid 365-370, mis olid suunatud shamaani pojale:

\author{
Tamaani, tamaani! \\ Nü̈d sinu teed \\ vahetatud teeks nimetatakse väidetavasti. \\ Kuidas sa vahetasid oma tee? \\ Selle kui ära arvan, sinu kahel vibukesel (= pojal) \\ kuni täiejõuliseks saamise ajani häda ei tule.
}

Sageli jagunevad dialoogilised fragmendid kaheks pooleks, millest esimene kommenteerib vastust eelmises fragmendis esitatud küsimusele, teises aga formuleeritakse uus küsimus. Näiteks värsid 371-378, mille esimene pool väljendab rahulolu selle üle, et eelmises fragmendis esitatud oletus poja vahetatud tee kohta leidis kinnitust:

Tamaani, tamaani!

Ärgu sul olgu kombeks kannatada.

Kõiki tegemisi [ja] muresid ära tundmata ma ju ei lobise.

Sinugi mõistus ütleb: "Mu vanaisa loitsimine on õige."

Maal, kuhu sa suundusid,

kui kohale jõudsid, tagasipöördumise sõna kellelt kuulsid?

Kui see on nõnda,

[oma] poja Kataraku töö teada saad. (7)

Kirjanduse põhjal võin öelda, et sellised äraarvamised-ennustamised kuulusid kohustusliku osana kõigi nganassaani shamaanirituaalide koostisse. Pikema rituaali algusosas täitsid need niiöelda õige tee otsimise funktsiooni, mille puhul äraarvatu õigsuse kinnitamine pidi veenma nii shamaani kui ka publikut selles, et shamaan liigub probleemi lahenduse suunas õiget teed mööda ning ta abivaimud on võimelised teda aitama. Shamaanile ei tohtinud valetada - s.o. teadlikult kinnitada ta valede väidete õigsust. (8) Uskumuste kohaselt võrdub valeinformatsiooni andmine shamaani eksiteele juhatamisega, see aga võib osutuda saatuslikuks nii shamaanile kui ka kogukonnale (vt. näiteks Popov 1936:104-105, kus esitatakse lugu shamaanist, kes juuresviibijate halva nõu järele talitades kutsus esile rõugeepideemia, mis tappis nii shamaani kui ka hulga ta kogukondseid). Eduka rituaali 
lõpuosas aga oli shamaanil kombeks enne abivaimude laialisaatmist soovijatele ennustada. Vormiliselt ei erinenud ennustamine 'õige tee otsimisest', kuid sellega võis kaasneda ka arbumine trumminuia viskamise teel. Samas on meil lühemate laulufragmentide puhul tegemist mitte lihtsalt ennustamisega vaid adressaadi maagilise mõjutamisega. Shamaani vaatevinklist vaadates toimib maagia põhimõttel - kui mina ütlen õigesti, siis läheb sinul hästi. Võib-olla peitub selle taga usk abivaimude vägevusse - kui vaimud on suutelised nägema inimelu varjatud seiku, siis on nad suutelised seda elu ka kaitsma.

Mis pikematesse laulufragmentidesse puutub, siis on need palju poeetilisemad ning seetõttu ehk ka raskestimõistetavamad kui lühikesed fragmendid. Neis ei pöördu shamaan konkreetselt ühegi juuresviibija poole, kuigi võib nimeliselt mõnda neist mainida. Esimese rituaali puhul järgnes sõnadele alguses mõtlesin öelda lühike ülevaade hetkeolukorrast ja shamaani ees seisvatest probleemidest (värsid 65-75):

\author{
Algul mõtlesin öelda: \\ kesksuve jumala päeval, \\ kasepuu kasvamiseks sobival, \\ haava kasvamiseks sobival, \\ paljasarvelise metsiku põdra kasvamiseks sobival, \\ [mu] lehestiku auklikuks muutumisel, \\ sel päeval kui \\ mu kaugeltsaabunud külalised sisenesid, \\ ainus mu sugulane, \\ Tolja-poeg, mu pojake \\ kaks rauda lahti tegi.
}

Teise rituaali käigus järgnes sõnadele algul mõtlesin öelda samuti ajaline piiritlemine, shamaan rääkis suve lõpust ja sügise lähenemisest, nimetades ühtlasi, et käesolev kuu (august) on tema Moskvareisi kuu (Seal käis ta 1988. aastal). Edasi tegeles shamaan mõlema rituaali ajal peamiselt oma kodakondsetele ja iseendale hea käekäigu tagamisega, kusjuures maagiline toimimine seisnes ühelt poolt selles, et ebasoovitav välistati sõnadega, teiselt poolt aga selles, et ebakindlale ja ajutisele otsiti tuge kindlate ning püsivate nähtuste juurest. Näiteks esimese rituaali värsid 93-109:

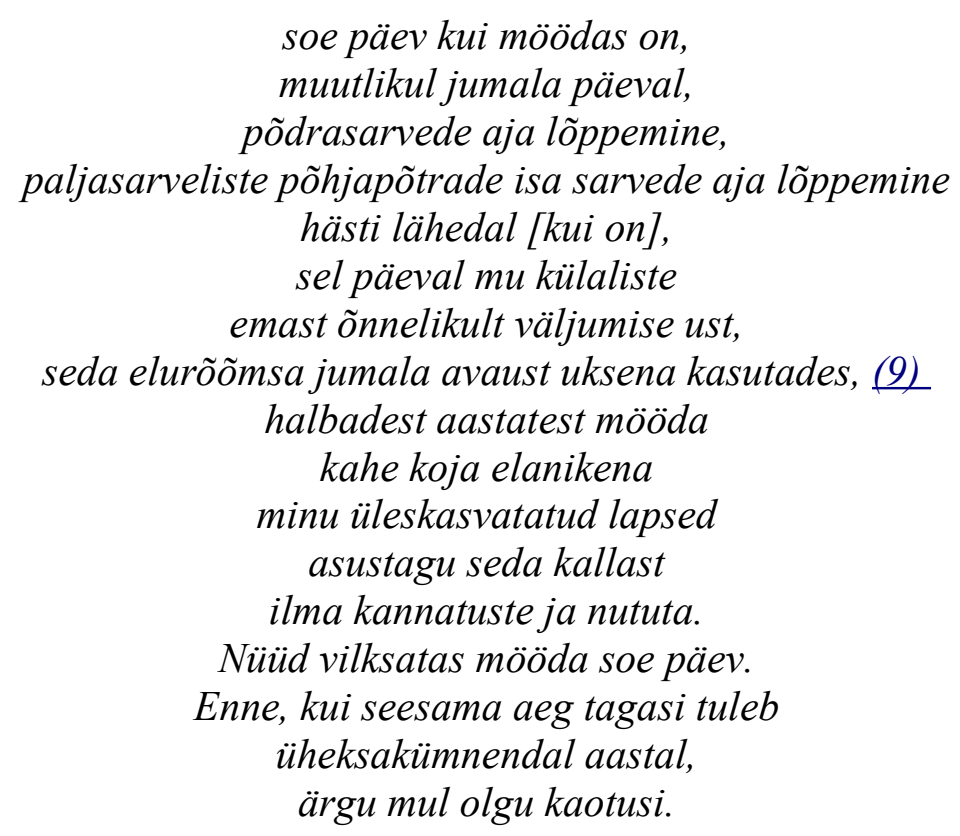


Või teise rituaali värsid 559-568:

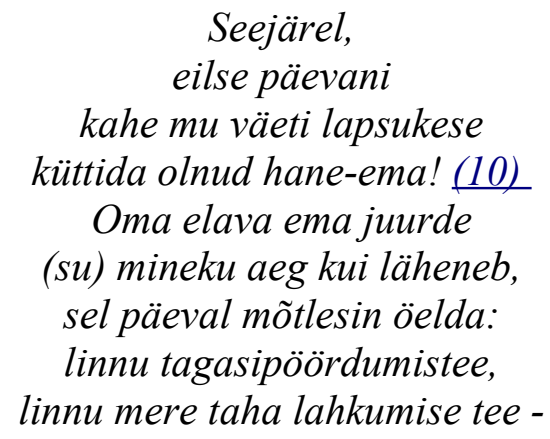

ja värsid 632-638:

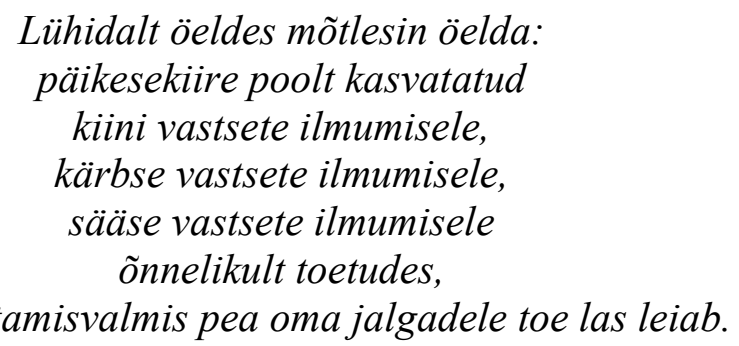

Võib öelda, et pikemad rituaalifragmendid koosnesidki mitmesuguste seoste loomisest mõjutatavate asjade ja shamaani poolt esiletoodud maagiliste etalonide vahel. Kindlad asjad ja regulaarselt esinevad loodusnähtused pidid tugema ebakindlaid, ühtede inimeste onnn saama toeks teiste inimeste õnnele, tundmatu pidi tuntuks saama ammutuntuga seostatuse läbi. Ei tohi unustada, et inimene, kes neid seoseid lõi, teadis tohutul hulgal muinasjutte, muistendeid ja laule. Ilma suulise pärimuse hea tundmiseta poleks sellise teksti improviseerimine võimalik olnud.

Teise rituaali pika laulufragmendi ajal pöördus shamaan abi või moraalse toetuse saamiseks ka mitmete üleloomulike olendite poole. Näiteks värsid 498-500:

seda päeva sihtides,

kõrvuline silmiline kuu,

tõepoolest vaata tagasi! (11)

ja 514-517:

$$
\begin{gathered}
\text { järgilauldud loitsu kuulav kuu, } \\
\text { kõrvuline kuu, } \\
\text { silmiline kuu } \\
\text { mind aidaku! }
\end{gathered}
$$

või 575-579:

\author{
täna jonnakas, \\ minu jonnakas pea, \\ tugeva metsiku põhjapõdra ema, \\ tugeva metsiku põhjapõdra isa, \\ metsiku põhjapõdra isa kaitseks on pannud
}


või 625-627:

$$
\begin{gathered}
\text { Päeva valdav jumal, } \\
\text { tõepoolest kunagi ööbinud mina kui olen } \\
\text { üheskoos praegu keerleva päikesega }
\end{gathered}
$$

või 663-664:

$$
\begin{gathered}
\text { Karu isa, karu ema, } \\
\text { täna kuulake! }
\end{gathered}
$$

Tegelikult tuleks eelnimetatud kategooriasse arvata ka Tubjaku pöördumised või viited nõukogude võimule, kommunistlikule parteile ja Leninile, sest needki olid tema jaoks ühelt poolt üleloomulikud jõud, teiselt poolt aga püsivuse ja kindluse võrdkujud. Näiteks esimese rituaali värssides 124-129 kasutab Tubjaku nõukogude võimust rääkides esimese isiku omastusliidet:

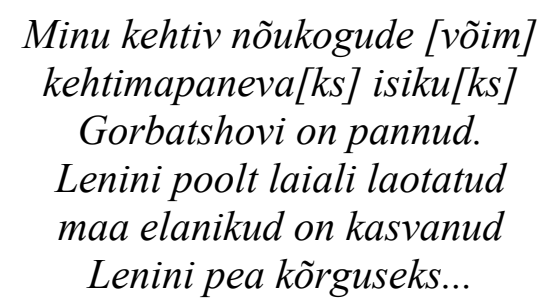

Teise rituaali värssides 597-610 üritas Tubjaku nõukogude võimu kaitsta võimalike kallalekippujate eest. Võib-olla mõtles ta peaaegu kummuli pööratud kojakoha all kogu N. Liitu?

$$
\begin{gathered}
\text { Mu külaliste pärast, } \\
\text { praeguste mu külaliste pärast, } \\
\text { pahupidi kummulipööratav juba } \\
\text { mu kojakoht saagu otseks. } \\
\text { Lenini poolt kehtestatud } \\
\text { täna elav } \\
\text { lenini partei nimi, } \\
\text { lenini komsomol, } \\
\text { nõukogude võimu kehtimine. } \\
\text { Mõni pahale meelestatu tugevat seadust ärgu närigu! } \\
\text { Lenini poolt kehtima pandud } \\
\text { isade seadus, } \\
\text { emade seadus. }
\end{gathered}
$$

Mõlema rituaali ajal seostas Tubjaku öeldu õigsuse ka eriliste märkidega taevas. Esimese rituaali lõpusõnadeks on (värsid 331-333):

$$
\begin{gathered}
\text { Kui mul on tegelikult õigus, } \\
\text { siis päevatõusu pool } \\
\text { väidetavasti on täiesti ilmselt nähtav jumala muster. }
\end{gathered}
$$

Teise rituaali pikk fragment lõppes samalaadse kuulutusega, lisaks seostas Tubjaku oma = Hotarie sõnade õigsusega ka kõigi juuresviibinute õnne (värsid 709-716):

Täna, mu lapsukesed,

kui mul on tõesti õigus,

[siis] päikese loojumispaigas

tume must pilv on väidetavasti nähtav.

Sellist kui näete, 


\section{tänast mu kõnelevat kindlat kuju \\ toena kasutades halbadest aastatest mööda kannatusteta elate.}

Viimased kolm värssi annavad ühtlasi aimu sedalaadi rituaalide eesmärgist. Shamaanirituaal peab juuresviibinutele kindlusetunnet andma. Kui märgid kinnitavad, et shamaan rääkis õigust, siis võib ka edaspidi julgesti tema ja ta abivaimude peale loota. Tubjaku ütles otsesõnu, et kindel ja tõtt rääkiv shamaan on see, kellele toetudes ületatakse kõik raskused. Ta oli teadlik oma missioonis nagu oli teadlik selleski, et tema surmaga lõpeb suurte shamaanide aeg Avami tundras. Esimese rituaali värssides 282-285 ütles ta:

\section{Shamanismi [ja] iidolite poole pöördumise kiiresti lõppev[al] päev[al] minu asemel laps ei hakka transsi minema. \\ Kõik loitsimise jaoks kõlblikud kompsu mähin, ainuüksi saab olema nõukogude seadus.}

\section{Kirjandus}

Eliade, M. 1974. Shamanism. Archaic Techniques of Ecstasy. Princeton.

Gratsheva, G. 1979. K knige D. K. Zelenina "Kult ongonov v Sibiri". Problemõ Slavjanskoi

etnografii. Leningrad 1979, s. 193-204.

Gratsheva, G. 1981. Shamanõ u nganassan. Problemõ istorii obshtshestvennogo soznania

aborigenov Sibiri. Leningrad, s. 69- 89.

Gratsheva, G. 1983. Traditsionnoe mirovozzrenie ohhotnikov Taimõra. Leningrad.

Kosterkina, N., Helimski, J. 1994. Malõje kamlanija bolshogo shamana. Taimõrskii

etnolingvistitsheskii sbornik. Moskva, s. 17-29.

Popov, A. 1936. Tavgits\&otilde. Trudõ Instituta antropologii I etnografii, tom I võ pusk 5. MoskvaLeningrad.

Popov, A. 1984. Nganassanõ. Sotsialnoje ustroistvo I verovanija. Leningrad.

Simtshenko, J. 1968. Nekotorõje dannõje o drevnem etnitsheskom substrate v sostave narodov Severnoi Evrazii. Moskva, s. 194-213.

Loitsude tekstid on tõlgitud kogumikust Taimõrskii etnolingvistitsheskii sbornik. Moskva 1994, 1k. 30-106.

- 1 viis tähtsamat abivaimu

- 2 Etteheide pojale Labtimakule, kes külaliste tulekust teades sõitis ära ega osalenud eelmisel rituaalil.

- 3 Nganassaanidel peetakse vanemaks vennaks ka isa nooremat venda (siin Boriss Kosterkinit), vanem õde on tema naine (Sandimjaku). 
- 4 Kogu fraas tähendab seda, et nimetatud isikute osalemisest eelmises rituaalis oli vaimudele vähe, juures oleks pidanud olema ka Tubjaku poeg ühes naisega.

- 5 1988. aasta augustis käis Tubjaku Moskvas folkloorifestivalil. Tema sõnade kohaselt oli Mikulushka Raudhobune temaga kaasas.

- 6 Vaimude toidu all tuleb muidugi mõista alkoholi, millega iga saabunud abivaimu shamaani suu kaudu kostitati.

- 7 Tähendab - Labtimaku elab vähemalt nii kaua, kuni poeg tööl käima hakkab.

- 8 Ka kõnealuste rituaalide ajal manitseti juuresviibijaid korduvalt, et tuleb öelda nii, nagu asi tegelikult on.

- 9 Tubjakul näis olevat veendumus, et tema kaugeltsaabunud külalised on eriti õnnelikud inimesed, sellepärast püüdis ta oma lähikondsete õnne külaliste silmnähtava ja kindla õnnega siduda. Eriti ilmekalt avaldub see püüdlus teise rituaali värssides 648-652: Tänaste mu külaliste, / mu õnnelike lapsukeste / seniseid elusid toena kasutades / täna komistamisvalmis / komistamisvalmis mu pea...

- 10 Leonid Kosterkin koos naisega jõudis just eelmisel päeval hanejahilt tagasi.

- 11 Siin ei pea Tubjaku enam silmas kalendrikuud vaid kuud kui jumalust. 